\title{
The Development of Low-Income Settlement by Community Driven Strategy and Introducing Batik Home Industry
}

\author{
Paulus Bawole, Puspitasri Darsono, Eko Agus Prawoto, Winta Guspara \\ Duta Wacana Christian University, Yogyakarta, Indonesia
}

\begin{abstract}
Indigenous people demonstrate great ingenuity in developing their residential neighborhoods and improving their living standard. The poor in low-income settlements is an example of indigenous people living in urban areas. If they are given a chance to develop their houses and surrounding areas as well as their living standard, they will show their great capability to improve their settlements, because they know exactly what they need and they know also their capabilities regarding their financial activity. To improve the environmental quality of low-income settlement, it is better and more sustainable, if the inhabitants are involved at the whole process of development. Community driven strategy is a total participatory development which enhances the potencies and minimizes the problems of low-income settlements based on community needs and closely assisted by facilitators. This strategy is very useful for improving the environmental quality within the low-income settlements. To enhance their living standard, those people living in low-income settlements need an income generating activity that is familiar with their daily life. The real batik cloth is a piece of a deep philosophical artwork for it contains prayer and hopes for the person who wears it. Resiliency in batik as an intangible cultural heritage can be achieved by encouraging batik making as a way of life as well as a way of make a living. Therefore, batik making should become a skill for the common, including the challenged one.
\end{abstract}

Keywords: low-income settlement, batik home industry, community driven

Worldwide, urban areas continue to attract large number of people due to the economic opportunities they offer. Globally, the shelter conditions of the poor are deteriorating: One point three (1.3) billion people do not have access to clean water and the same number live on less than a dollar a day; 2.6 billion people do not have access to basic sanitation, while five million die from diarrhea diseases every year. Poverty will clearly dominate the international development agenda of the 21st century. Much of the focus of this agenda will be on the world's urban areas where an estimated one billion people still lack adequate shelter and basic services (Tebal \& Ray, 2001). Even though they live in bad environmental areas within the city, the formation of their housing areas is an integral part of development of a city.

In formal settlements, the character of urban form has been developed in accordance with the plans that

\footnotetext{
Corresponding author: Paulus Bawole, Dr.-Ing., Ir., MIP., Faculty of Architecture and Design, Duta Wacana Christian University, Yogyakarta, Indonesia; research field: housing and urban design. E-mail: paulus_bawole@yahoo.com.

Puspitasri Darsono, Dra., M.Sc, Faculty of Architecture and Design, Duta Wacana Christian University, Yogyakarta, Indonesia; research field: product design. E-mail: pipitsky@yahoo.com.

Eko Agus Prawoto, Ir., M.Arch., Faculty of Architecture and Design, Duta Wacana Christian University, Yogyakarta, Indonesia; research field: building and urban design. E-mail: ekoprawoto@yahoo.com.

Winta Guspara, ST., Faculty of Architecture and Design, Duta Wacana Christian University, Yogyakarta, Indonesia; research field: product design. E-mail: abot110@yahoo.com.
} 
have been made before. Meanwhile, the growth of low-income settlements develops sporadically without any planning, hence the spatial pattern of the settlement formed also becomes irregular (Bawole, 2007). Because the people who live in low-income settlements are poor and live in settlements that have minimal infrastructure facilities, they must be creative in developing their residential areas. Creativity to develop specific urban forms is quite different from standards that exist in the literature. With appreciating the creativity of low-income community in doing the architectural activities, community housing development strategies can be developed according to the character of its inhabitants.

The most difficult situation faced by the poor in informal settlements is that their living standard is very low. Mostly the income gotten during a day can only be used by the family for living in one or two days. This means it is quite difficult for them to save their money for upgrading their houses. Therefore, the quality of their houses as well as their surrounding environment is not so good. To enhance their living standard, it is necessary for them to introduce activity that can rise their daily income. Batik home industry is appropriate for the people, because it is common for all people in Java including the low-income community and the process is not so difficult. If the poor in low-income settlements are given a chance to carry out upgrading for housing and their living standard, they will show their capability to implement ecological and social approach in handling their housing problems including their family income, even though in a very simple way.

\section{Basic Theories of Spontaneous Settlement}

People in low-income settlement develop their housing areas spontaneously without any planning, they do not have any background knowledge in architecture or urban planning and design. What they develop is only to fulfil what is needed and necessary for their daily life, even though many people or government stigmatize them low-income settlement (Wakely, 2010). Based on the observation in several low-income housing areas in four cities, the problems of the informal settlement begin to appear when the local government considers the low-income settlement as a bad image of the city that must be removed.

The grass root people in informal settlement do not have a chance to live in formal settlement, because they are too poor to reach the formal housing prize. In other words, it is quite difficult for them to save their money for their future better live (United Nations Centre for Human Settlements [UNHCS], 1996). The only alternative to stay around the city center is in a piece of land in which they do not have to buy the land or to pay for the rent. At those vacant areas automatically, there are no adequate infrastructure facilities, but the grass root people with their great ingenuity can struggle for their life. Since they live in low-income settlement with minimal infrastructure facilities, they have to be creative and used the facilities within the settlements effectively (Hardoy, Cairncross, \& Satterthwaite, 1990).

Spatial form in informal settlements can be seen as public open spaces and pathways in which many people carry out their daily activities. After finding out the spatial forms including inhabitants' activities inside, it is necessary to choose several active open spaces within informal settlements and then use them as an orientation of the plan for urban revitalization program. The active open space is chosen because it is a place used as a centre for human activities in the settlements. The circulations connecting the open spaces available should be considered as a secondary pattern of the settlements, because the main pattern of the settlement is linear pattern following the river flow. Afterwards the houses developed along the circulations or pathways should be improved step by step individually with the strategy of self-help development (see Figure 1: an example of self-help housing development in Mexico City). 
Understanding the activities of the poor in architectural space within the informal settlements is very useful for arranging a development strategy based on the character of the inhabitants. By paying attention to the economical situation of the low-income people living in informal settlements, it can be understood that they are hard workers, who are persevering in looking for their basic necessities of life for their family (Nierman, 2005). Not only the husbands work, but also the wives work to help their husband in order to have additional incomes. It is better for the poor in low-income settlement to introduce batik home industry using inclusive and eco-design strategy. Their dependence to the centre in the bustle of the city is very strong, because in the centre, they can get their income everyday.

Batik as a way of Javanese life for centuries has found its place in the industrial era. From birth till death, Javanese has been using batik cloth for daily life as well as rituals. In the past, it was the man who wrote their prayer-djopo - in the form of batik pattern on a piece of fabric and the woman delivered the prayer into existence - noto — by a meticulous technique of putting hot wax on the pattern using a tool called tjanthing. The act of Djopo Noto which also symbolizes that Javanese man and woman have made batik as a piece of a deep philosophical artwork for it contains prayer and hopes for the person who wears it. Resiliency in batik as an intangible cultural heritage can be achieved by encouraging batik making as a way of life as well as a way of make a living.

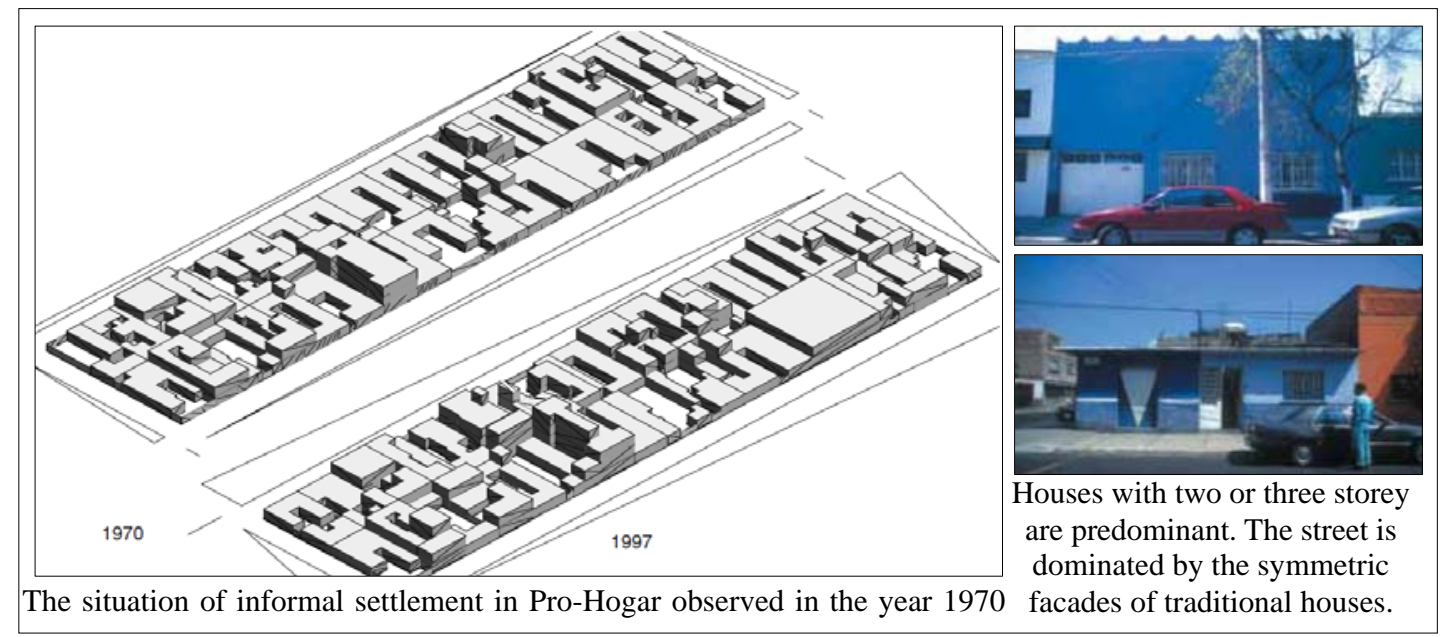

Figure 1. Informal settlements in Mexico City developed with the strategy of land consolidation, housing development with using the self-help strategy. Source: Ribbeck (2002).

\section{Typology of Low-Income Settlement in Indonesia City}

The development of cities is never ending, except there is a disaster that destroys the city. War, fire, and natural disasters like earthquake, flood, volcano eruption, and hurricane can easily destroy the city. In general, the urban form of the city in developing country like Indonesia can be divided into formal urban form and informal urban form. The urban form in low-income settlements is developed without any plan. Since the inhabitants have a poor situation in economic and education, their capability to develop the surrounding environment is also poor (Cody, 1996). As an illustration, the sporadic development of the poor housing areas likes pouring the water directly to the floor. The water is spreading out on the floor without any form. The spreading water in the illustration likes the spontaneous development of urban area within the low-income settlement (see Figure 2). 


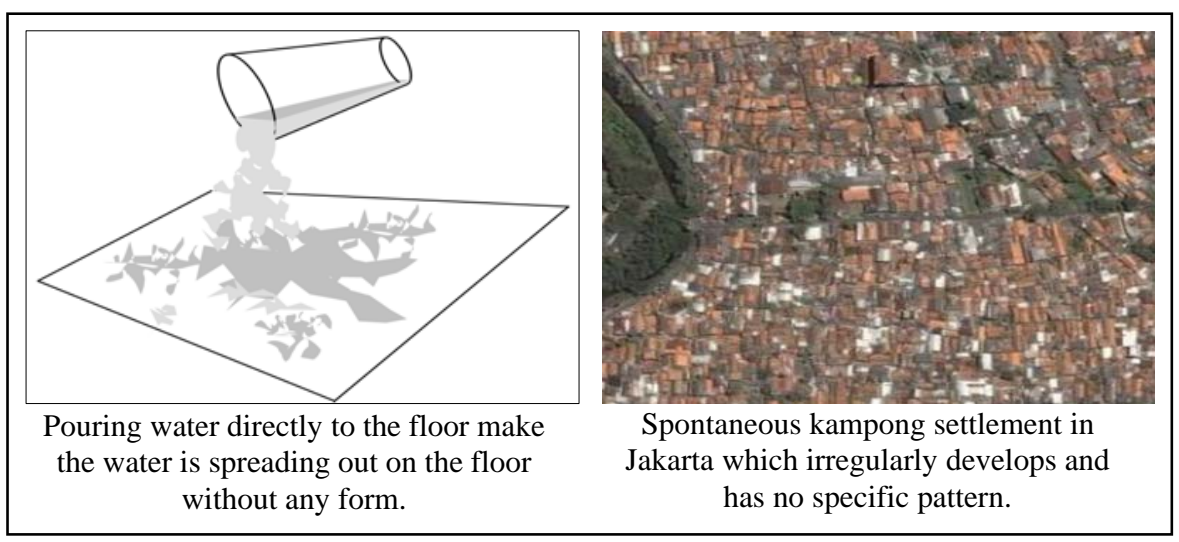

Figure 2. Urban form in low-income settlement.

\section{Urban Form in Low-Income Settlement}

In general, the development of informal urban form is on a hidden area of major urban roads. The growth of informal urban form is always behind the shopping areas, on the edge of the river valleys, along the rail way track behind houses built formally and some vacant areas that cannot be seen from the main road. Those places are chosen by the poor, because they do not have to pay some money and the location is not too far from the place where they get their daily income (Srinivas, 2015).

Unlike formal urban form which is planned perfectly, the informal urban form development is done spontaneously by the low-income communities. Therefore, informal urban form often referred to as unplanned settlement or irregular settlement. The uniqueness of the urban form of the low-income housing areas is the development process which is highly customized to the needs of local communities and the availability of building materials which they can gather around their home. The urban form is very sample and usually the available open space is not so big, but the community uses the space very intensive. Sometimes, the children use the street in front of their house as a playing lot, if there is no open space around their house.

\section{Architectural Form of Houses in Low-Income Settlements}

Houses in low-income settlement have different characteristics, even though in general, they can be distinguished as permanent, semi-permanent, and non-permanent buildings. The architectural typology of the houses in low-income settlement is relatively simple with a quadrangle ground plan and the building orientation is toward the kampong's pathway or to public open spaces. There are usually two entrances to the house: the main entrance from the front of the house and a side entrance at the back of the house. Some houses built with permanent qualities, but the quality of building materials is low. Upper low-income people who have monthly income build mostly the permanent houses. Whereas, the non-permanent houses are built by the grass root people who work in informal sectors.

The roof form is dominated by the simple Javanese traditional form called "kampong" and "panggang pe" roofs. The other forms, like Limasan, Tajuk, and Joglo, have been found only on a few houses (see Figure 3). Generally, a house with a complex form of roof is owned by the upper low-income people or the middle class. The community usually uses the Panggang Pe types for building small kiosks nearby their house. The people use Kampong types for the roof of their house, because the construction is very simple.

The people use cement construction for the floor material in their house, but many of them still use soil floor without any finishing for their house. For the middle to upper low-income people, they use ceramic tile 
for floor materials. Whereas, the grass root people put the used tile materials for the floor or they just leave the floor from soil. All houses are equipped with varies size of windows and mostly have ventilation above for maintaining air cross ventilation in the house.

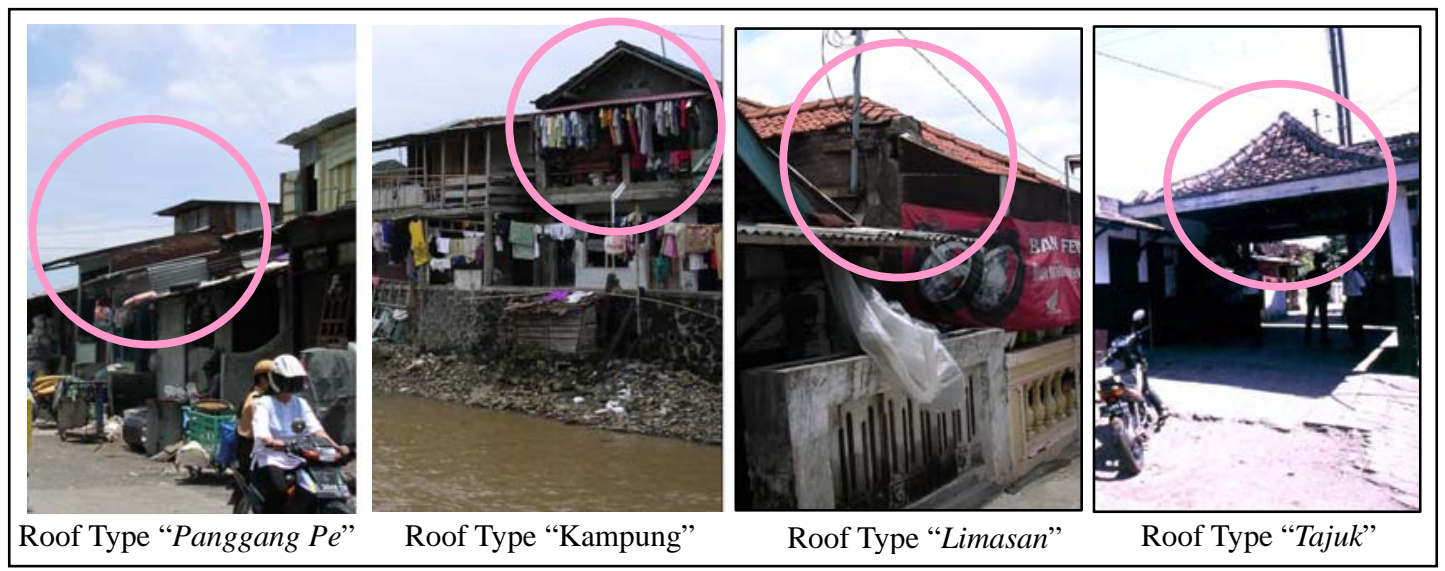

Figure 3. Roof types of informal houses along the riverbank in Indonesian cities.

\section{Character of Public Open Space in Low-Income Settlements}

There is no specific form of public open spaces in informal settlements, because the forms and sizes of the open spaces depend on the remind spaces which have not been used for expanding the houses. The public open spaces in informal settlements are very limited. Therefore, some people in low-income settlement use the kampong streets or pathways for their social interactions. Usually youth and children use the street or pathways for their interactions and playing (see Figure 4).

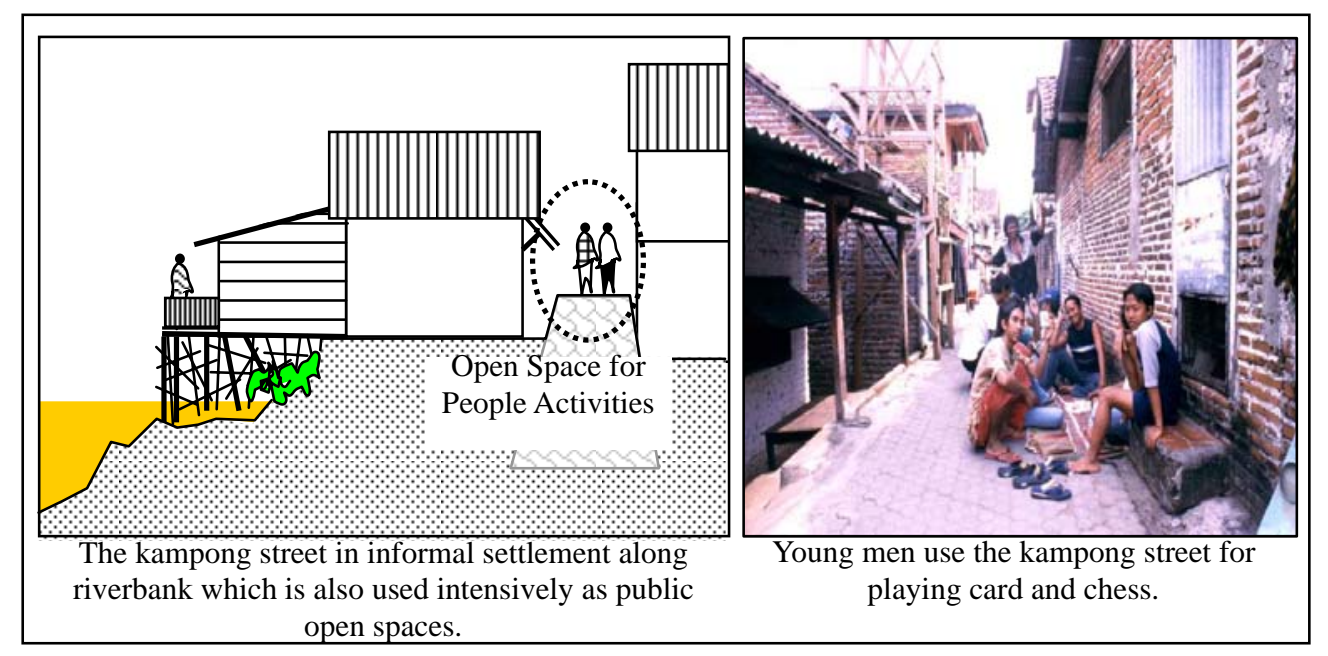

Figure 4. Spontaneous public spaces within informal housing areas along the riverbanks.

In general, the public open spaces surrounded by several houses are actively used by the people for their social interactions. If in the open space, there is a social or technical infrastructure facility like public well, kiosk, water tap, etc., the open spaces are mostly used by the inhabitants for maintaining their social relationship. 


\section{Creativities in Developing the Settlement}

According to Hardoy, poor people demonstrate great ingenuity in developing these new residential neighborhoods and in organizing the construction of housing - even if government regards them as illegal. Their ways, their plans, their designs, and their building materials are often far better suited to local needs, local incomes, local climatic conditions, and local resources than the official, legal standards demanded by governments. This happens because official standards are derived from Western models which have little relevance to local circumstances and take no account of local climate, local preferences, and availability of local building materials (Hardoy \& Satterthwaite, 1989).

In low-income housing areas, poor people develop their houses first with very simple materials such as pieces of cardboard, plastic, bamboo, or wood. During certain times, the housing area grows spontaneously. Many poor people will build their houses in the same areas. Open spaces, alleys, pathways, and streets are formed spontaneously too. Therefore, the creativities in dealing with minimum infrastructure facilities can be seen in the design of their housing areas such as settlement pattern, public open spaces, building architecture, landscape, infrastructure, etc.

Research has shown that slums are in fact often highly organized both spatially and socially that their occupants participate fully in the urban economy, that they are culturally diverse and dynamic, and that their residents are motivated, entrepreneurial, and not delinquent. Some established slums have within them vibrant local economies, dynamic informal housing and land markets, and diverse social and cultural groupings, while some slums are indeed characterized by squalor, disease, acute poverty, and exclusion (Bawole, 2007).

Although the people come from different regions, they are able to live together in harmony. It can be observed when one family needs help, many other families will extend their hand to give their help. The relationship among the people living in the low-income settlement is very close (Wilcox, 1994). It is not limited by the difference of ethnic group, religion, and race. Hence, the potency can be used as a tool for improving the environment quality of their housing areas, because it is not so difficult to stimulate the poor in low-income settlement to work together (gotong royong) in order to make their housing areas healthy and environmental friendly.

\section{Improving the Quality of Kampong Road Pattern}

As it was mentioned before that the informal settlements were developed spontaneously without any planning. Consequently, there is no certain pattern of circulations within the settlements. The combination between the main pathways and any other small pathways or alley makes the settlements special. The main pathways are very important for the inhabitants, because many inhabitants use them as a public space in which they are doing their social interactions. The circulation/path way in informal settlements has special characters which are influenced by the position of houses and have several variants in width (Bawole, 2010).

Usually, circulation pattern in informal settlements is linear following river flow or the street. If the settlement is developed in steep areas, the circulation pattern is perpendicular to the river or street. If the main circulation is developed in the middle of the housing areas, the front façade facing the street has better performance compare with the back. If it is developed along the riverbanks, the inhabitants will throw any waste they produce every day directly to the river. The other secondary circulations in the settlements do not have special pattern, because they were developed spontaneously following the pattern of housing areas. There are many small streets, tiny paths, or alleys usually called mouse path (Narrow Street) which are used by the inhabitants as an alternative circulation to the main street. 


\section{Using Public Open Spaces by Time Sharing}

The open space in informal settlements has been formed spontaneously, because the houses are developed without any planning. The spaces do not have certain patterns and form, but the inhabitants use the open spaces very effectively. From the field observation, it has been obtained that there are some circumstances, which stimulate the activity of the inhabitants in open spaces or on the kampong's pathway. One of them is the availability of the open space as an orientation of some houses. By facing to the one open space, the communication and the social interaction among the families living in the houses can be involved well. Generally, the open space that explained above will be used effectively by the inhabitants: children, young man, and adults. They use the open space within the settlements by time sharing or they use the open spaces by turns. The other activity stimulation is the available technical infrastructure facilities in open space, like public water tap, public well and also social infrastructure facilities like guarding house, food stall, musholla (small mosque), etc. Those infrastructure facilities above can often stimulate the people activities in order to make a social interaction and communication among them.

Based on the field observation, the open space in the settlement is very important for social living of the people. Observing the socio-culture of the people living in the informal settlement, all of the members of the society, the children, youth, women and men, have always social interaction among them in the open space. If there is no open space in the settlement, they will do the social interaction on the public pathways nearby their houses. Especially for the children, the public open space has a special meaning for them to play and express their creativity. Besides, the open spaces are needed very much for the settlement with dense built-up areas, because they have a function as a place for air circulation in the settlement.

\section{Developing Strategy for Improving the Living Quality}

Low-income settlements are available almost in all big cities in Indonesia. Understanding the activities of the poor in architectural space within the informal settlements is very useful for arranging a development strategy based on the character of the inhabitants. By paying attention to the economical situation of the low-income people living in informal settlements, it can be understood that they are hard workers, who are persevering in looking for their basic necessities of life for their family (Nierman, 2005).

The most difficult situation faced by the poor in informal settlements is that their living standard is very low. Mostly the income gotten during a day can only be used by the family for living in one or two days. This means it is quite difficult for them to save their money for upgrading their houses. Therefore, the quality of their houses as well as their surrounding environment is not so good. In a certain situation, the poor in informal settlements should learn how to save their money; otherwise, they will continue to live in a bad housing environment. The only possibility to promote saving is that they have to set up a group of families and then every family has to save certain amount of money. After the group has enough money, they can arrange to upgrade their houses and the surrounding environment. If the poor in informal settlements is given a chance to carry out upgrading, they will show their capability to implement ecological and social approach in handling their housing problems, even though in a very simple way.

Besides forming saving groups, which is consisting of families living in low-income settlement, the poor people also need another strategy to improve their living standards. Since batik is identical with all people in Indonesia, a strategy to enhance the community's economy is introducing batik home industry, which is using inclusive and eco-design strategy. The real batik cloth is a piece of a deep philosophical artwork for it contains 
prayer and hopes for the person who wears it. Resiliency in batik as an intangible cultural heritage can be achieved by encouraging batik making as a way of life as well as a way of make a living. Therefore, batik making should become a skill for the common, including the challenged one (Clarkson, Coleman, Hosking, \& Waller, 2007). Hopefully with the ability to create batik, the people living in low-income neighborhoods that have either normal or difabel body can produce batik cloth. They can sell the batik cloth in the city center which is not too far from where they live (Mumtaz, 2001). Thus, the economic level of poor communities in low-income settlement can be increased gradually.

\section{Introducing Batik Home Industry Using Inclusive and Eco-Design Strategy}

As has been discussed above that the people living in low-income settlement are hard worker who are struggling to improve their standard of living. This community is quite varied characters ranging from young people to older people. In addition, there are some members of the community despite any disabilities either on the hands or feet. The section below will explain the results of the research associated with batik industry that is using inclusive and eco-design. With the results of this research to all community members in low-income settlements have alternative work that can be done at home while taking care of household activities. Results of this study will be introduced on the poor in low-income settlements through a participatory planning process with community-driven strategy that has been described above.

The discussion below begins with the observation hierarchical task analysis (HTA) which discusses the stages of batik process; discuss Nordic Body Map (NBM) which addresses the comfort of batik by normal people and difable; Rapid Upper Limb Assessment (RULA) to determine unnatural posture on upper bodies and parts on bodies that need correction; to study about hand grip; and developing eco-design which is explained by discussing DC Current Experiment, New Product Performance Specification.

\section{Hierarchical Task Analysis (HTA)}

HTA in creating batik showed that there are five steps in batik activities. Those steps are sitting position, putting cloth on hanger, heating wax, scooping liquid wax from pot, and drawing on cloth using canting. Eliminating one-step requires a technological intervention. Step four, which is scooping liquid wax from pot, requires the eyes to turn its gazing away from the cloth shortly in order to focus on scooping the hot liquid ax. When the eyes return its gazing to the cloth, it will need time to locate the motive that needs waxing. If step four can be eliminated, it will reduce work time.

\section{Nordic Body Map (NBM)}

NBM measurement of artisan with paraplegia: Spastic on legs will occur when the artisan does not take rest after two hours work. The sudden spastic leg may kicks hand that is holding canting full of hot liquid wax. The artisans always feel uncomfortable on waist and buttock because of their sitting on wheelchair. This problem will increase after working for four hours and decrease after one hour rest. But the whole complaints will only subside after seven hours of rest. After working for four hours, the artisan also feel pain on both upper arms and hands, right thigh and both sole of feet. The pain on these areas subsides after one hour rest.

NBM measurement of artisan with brachydactyle showed that there are no complaints before work. All parts of body are in pain after four hours of work, except on both elbows (see Figure 5). The pain is reduced after one hour rest, except for right shoulder, right thumb, and right sole of foot that are used to support body while working (Dominica \& Sutalaksana, 2000). 


\section{Rapid Upper Limb Assessment (RULA)}

RULA measurement showed that the activity "Taking and Putting Cloth on Hanger" is scored 6, while the activity "Scooping Liquid Wax with Canting" is scored 5 (see Figure 6). This means that both activities need further research and immediate change to reduce work risk. Meanwhile, the activity "Doing Batik" is scored 3, which means that it needs further research and necessary changed (Setyawati, 2001).

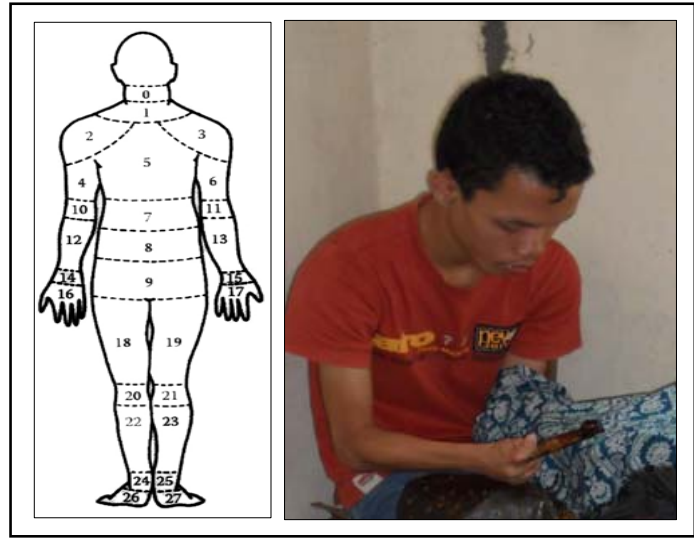

Figure 5. Nordic Body Map (NBM).

Hand grip.

Internal Precision Grip

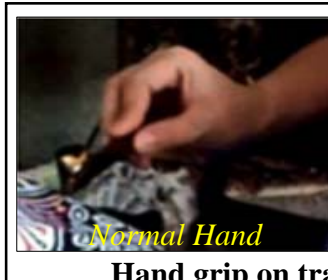

Hand grip on traditional canting

Normal hand grip is in dorsi flexi position.

While the brachydactyle artisan is using neutral

position because of his short fingers.

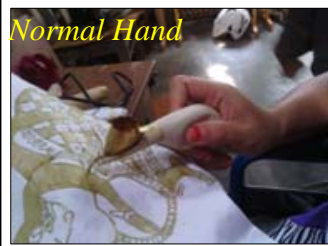

Neutral position hand grip

Neutral position is achieved by normal hand using Bennett Curve $19^{\circ} \pm 5^{\circ}$ handle

(McCormick \& Sanders, 1982). While the brachydactyle artisan's handheld-flops is in neutral position using small and flat handle.
External Precision Grip

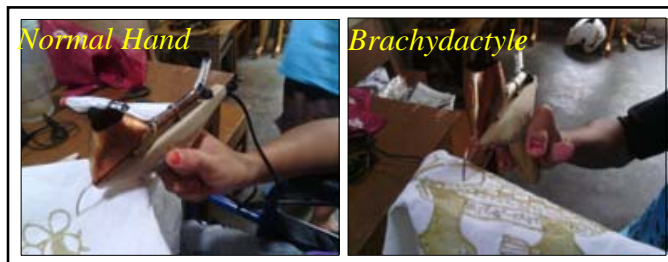

Handgrip on existing electrical canting

Both artisans are using dorsi flexi position because of the handle width is $5 \mathrm{~cm}$. They both feel uncomfortable because of the weight and width of handle.
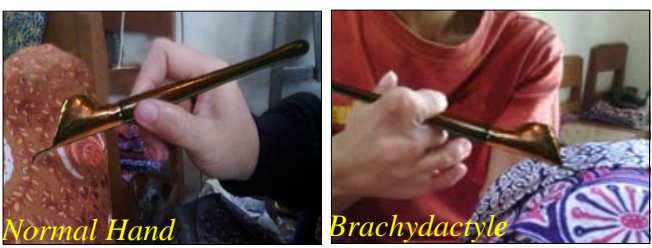

Agreement on handle design

Both artisans are using external precision grip (Helander, 1995) on thin, long handle. The normal hand is in dorsi flexi position because of the angle of wax container. The brachydactyle artisan is using handheld-flops because of his short fingers. Both feel comfortable on the handle design.

Figure 6. Internal and external grips.

Result of DC Current Experiment. Early experiment focused on the placement of nickelin coiling for 
optimum heating. The experiment concluded that nickelin coiling should be placed at the bottom-inside of the heating unit and along cable. Experiment in 12 Volt DC, current measured 1.68 Ampere, the electrical power acquired is 20.16 Ampere with 18 minutes heating time. Liquid starts to solidify at the edge of outlet that is not covered with nickelin. For installation longer than $5 \mathrm{~cm}$, it requires more than 20.16 Watt (see Figure 7).

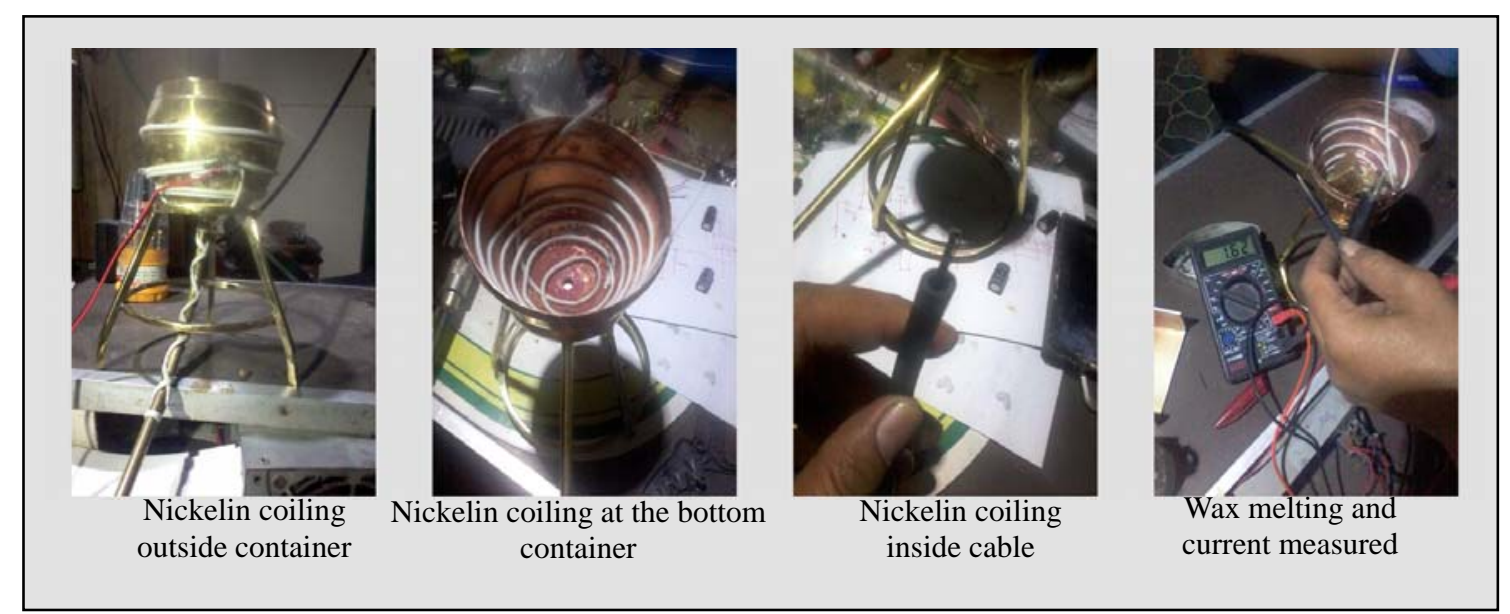

Figure 7. Nickelin coiling experiment.

\section{New product performance specification.}

(1) Thin-long handle using external precision grip for neutral hand grip position;

(2) Integrated heating and canting design to reduce work steps;

(3) DC Current 60-100 watt;

(4) HTA (Wilson \& Corlett, 2005) using step 1, 2, 3, and 5.

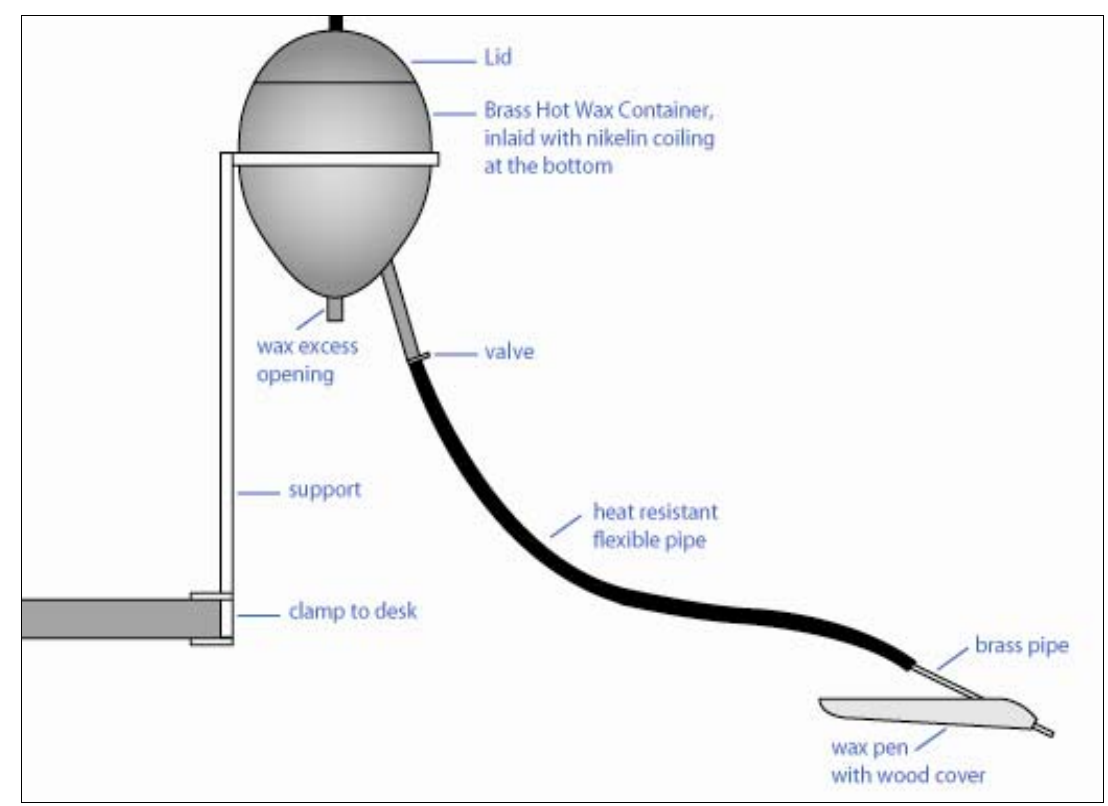

Figure 8. Diagram of new product.

Wax heating unit is connected with a cable which carrying hot liquid wax to the tip of pen (see Figure 8). 


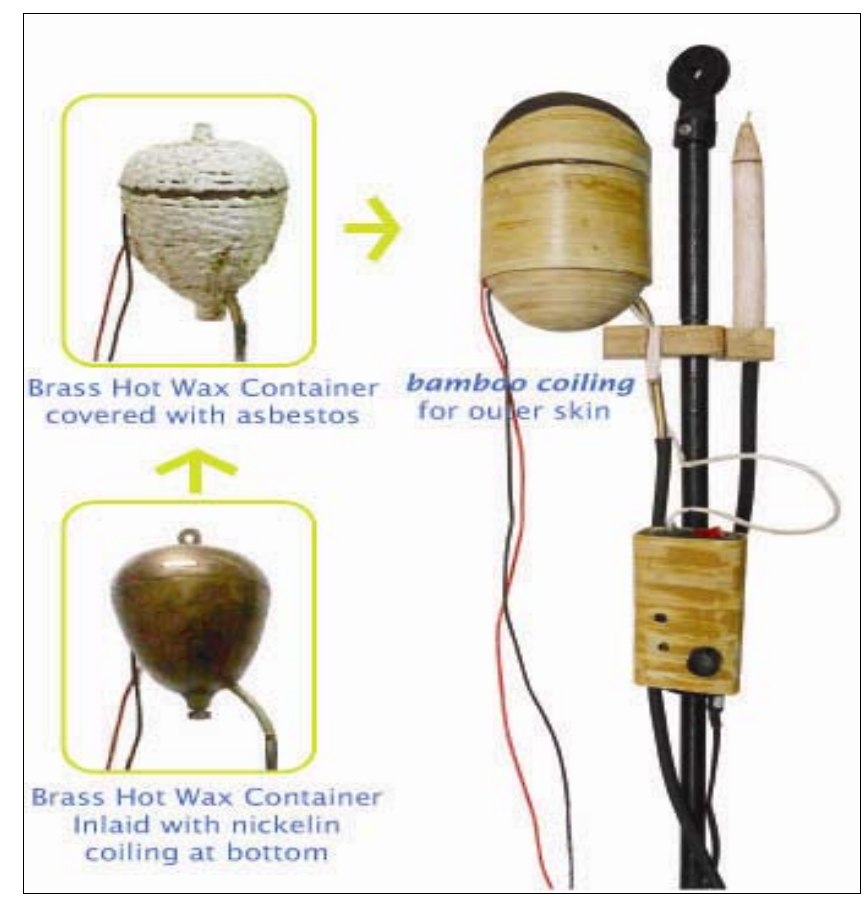

Figure 9. Integrated wax heating and canting model.

First prototype. Nickelin coiling is placed at the bottom inside the hot wax heater. The brass container has bamboo coiling as outer layer with asbestos filler. Switch panel and pen hanger is placed at a retractable pole support within arm reached (see Figure 9).

Putting wax block in heating container: User can easily pull and push the retractable pole support to adjust its height. But the height needs to be at least $150 \mathrm{~cm}$ high (see Figure 10).

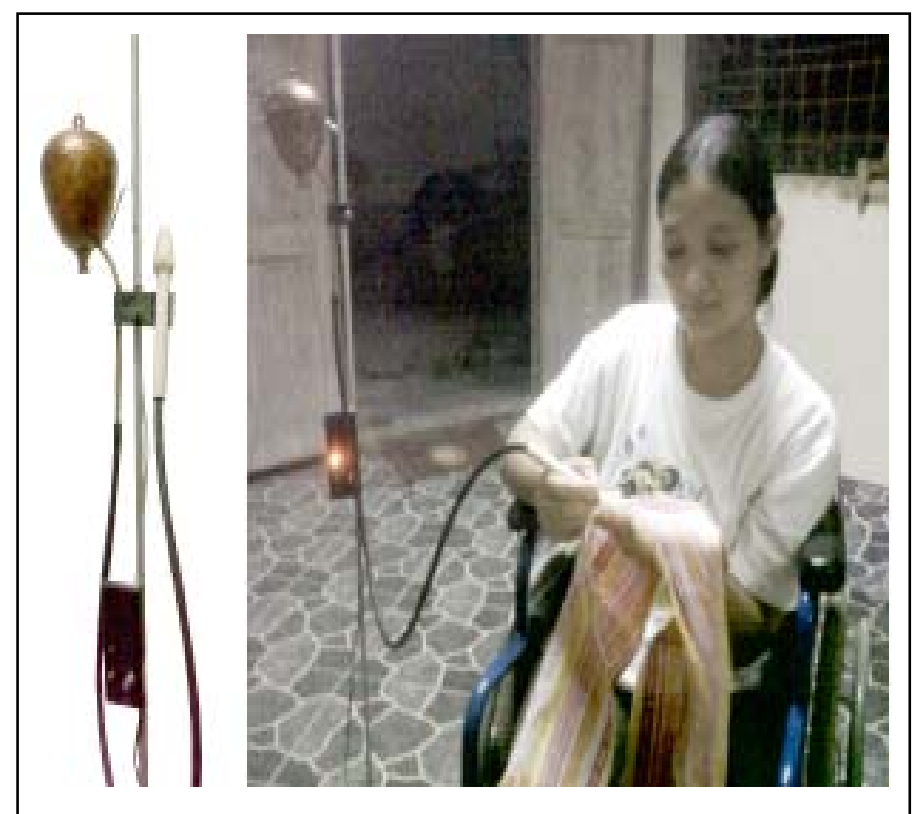

Figure 10. User test on new product.

Preparation to work: Switch button and wax pen at the middle of pole is within reach. 
Doing batik: Drawing lines and filling motives with liquid wax is done easily. The result has the same quality as using traditional canting.

Resting: A few moments after the switch is off, wax temperature is lower, liquid flow is slower so that when the pen is hanged, wax will not overflow.

Evaluation: Electrical cable needs to be tidy, hot cable needs to be covered, wood handle needs to have a better heat insulation, other immediate supplies need to be placed near user such as wax stock, different pen tips, and drinking glass.

Model elaboration. In order to lower the height of the wax heating container, this product use small pump for each pen. The container is now rest on $90 \mathrm{~cm}$ height from floor. It has a $50 \mathrm{~cm}$ in diameter desktop to put user's immediate supplies, and some drawers to keep other supplies. The work station can be used comfortably for three batik artisans (see Figure 11).

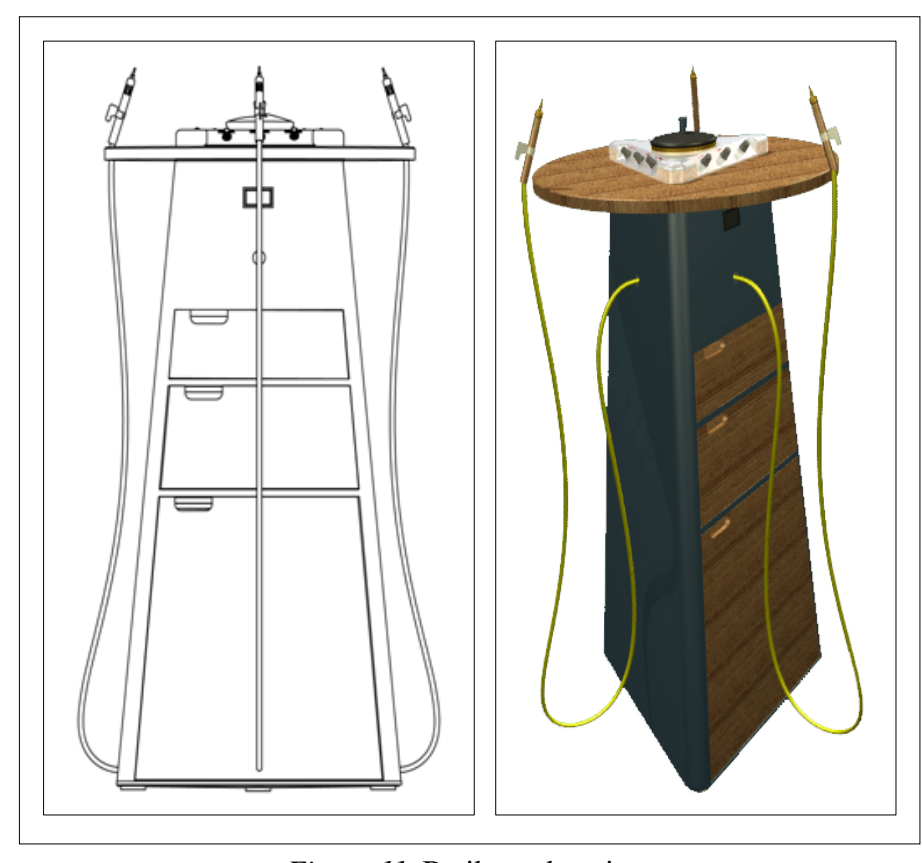

Figure 11. Batik workstation.

\section{Conclusions and Recommendations}

Through discussions carried out in several chapters above, it is necessary to have conclusions for developing the low-income settlements not only the physical aspects of housing areas, but also the economic activities of the inhabitants. After having the conclusions, the recommendations will be suggested for improving the environmental quality in informal settlements as well as the community's living standard.

\section{Conclusions}

Creative urban forms and architecture developed by the poor in low-income settlements will be taken into account as settlement potencies that can be improved. The conclusions can be stated as followed:

(1) Harmonizing the built and natural environment within the urban areas should give more attention to the low-income people, who live in low-income settlements;

(2) The possibility for the poor to express their capabilities and knowledge in order to improve their living standard should be given by the local government or non-governmental organizations (NGOs); 
(3) Batik home industry using inclusive and eco-design strategy is good for the low-income people in order to improve their living standard;

(4) Provide the conditions for the development of communities as residents have a sense of ownership;

(5) The removal of people from their homes in slums and their rehousing on alternative sites should not be the first choice of policy makers. Resettlement can destroy social networks and communities, and experience shows that new development can cost between 10 and 15 times more than upgrading the conditions in the places where they already are. Suitable land is usually scarce and resettlement destroys housing stock, compounding the problem of housing shortages.

\section{Recommendations}

Based on the discussion and conclusions written above, the recommendations are given as follows:

(1) City-wide strategies for low-income housing do not only need to address the backlog of housing shortages and upgrade large amounts of undeveloped areas, but also pay attention to the housing needs in the future;

(2) When people are forcibly evicted from their homes without the provision of acceptable alternative accommodation, they may create new squatter settlements or become tenants, increasing the population density and problems of existing slums. Whatever the motive behind a forced eviction, it cannot justify the means and only exacerbates housing shortages;

(3) It is very important to understand that social infrastructure facilities are needed by the inhabitants for carrying on their social interactions;

(4) Improving the community's living standard by introducing some alternatives economic activities, so that they can earn some money for fulfilling their daily need;

(5) Since batik is familiar for the low-income people, it is better for facilitators to give training and workshop about making batik;

(6) Do not send demolition squads and bulldozers in to raze houses when residents are still present. If residents remain this may indicate their opposition to resettlement, demolishing their houses in these circumstances constitutes forced eviction (see section on forced eviction above);

(7) Residents should be involved in all aspects of planning, including setting dates for resettlement, organizing transport, choosing the site they are to be relocated to and planning its current and future layout, housing, services, and infrastructure.

\section{References}

Asian Coalition for Housing Rights. (2003). Housing by people in Asia. Newsletter of the Asian Coalition for Housing Rights, No. 15, October 2003. Bangkok, Thailand.

Bawole, P. (2007). Informelle Siedlungen an Flussufern in Gefährdeten Stadtgebieten Indonesien, Indonesien (Informal settlements along the riverbanks in dangerous areas in Indonesian cities). Dissertation from Institute of Urban Design, the Faculty of Architecture and Urban Planning, the University of Stuttgart.

Bawole, P. (2010). Creative urban forms as a collaboration and environmental design developed by marginalized inhabitants. Proceedings from International Conference Arte-Polis 3. Architecture ITB, Bandung.

Bawole, P., Darsono, P., Prawoto, E., \& Guspara, W. (2015). Resiliency in batik industry using inclusive and eco design strategy. Proceedings of the 3rd ICCI 2015 Oportunity and Challange on Creative Industries in the Era of Global Free Trade, edited by Department of Industrial Design, Faculty of Civil Engineering and Planning. Surabaya: ITS Press.

Clarkson, J., Coleman, R., Hosking, I., \& Waller, S. (2007). Inclusive design toolkit. Cambridge: Engineering Design Centre, University of Cambridge. 
Cody, E. (1996). Poverty and environment-A problem or a solution? Habitat Debate, 2(2).

Dominica, M. R. T. D., \& Sutalaksana, I. Z. (2000). Analisis Ergonomis tentang Kerja Pembatik pada Industri Batik Tulis (Ergonomic analysis about batik worker in batik industry). Bandung: Industrial Engineering and Management, ITB.

Hardoy, J. E., \& Satterthwaite, D. (1989). Squatter citizen. London: Earthscan Publications Limited.

Hardoy, J. E., Cairncross, S., \& Satterthwaite, D. (1990). The poor die young. London: Earthscan Publications Limited.

Helander, M. (1995). A guide to the ergonomics of manufacturing. London: Taylor \& Francis.

McCormick, E. J., \& Sanders, M. (1982). Human factors in engineering and design. New Delhi: Tata McGraw-Hill Publishing Company Ltd.

Mumtaz, B. (2001). Why cities need slums. Habitat Debate, 7(3), 8-10.

Nierman, M. (2005). Armutbekämpfung in Städten (Combating poverty in cities). Eschborn: GTZ GmbH.

Ribbeck, E. (2002). Die informelle Moderne: Spontanes Bauen in Mexico-Stadt (The informal modernity: Spontaneous building in Mexico City). Heidelberg: Architektur und Wirtschaftsförderungs-Verlag.

Setyawati, L. (2001). Pengadaan Peralatan Kerja Yang Ergonomis, Perspektif Jender Bagi Pembatik Tulis Dalam Kaitan Dengan Tingkat Kelelahan Kerja dan Stres Psikososial (Procurement of ergonomic work equipment, gender perspectives for batik worker in relation to fatigue level of work and psychosocial stress). Pusat Studi Wanita, UGM.

Srinivas, H. (2015). Defining squatter settlements. The Global Development Research Center. Retrieved from http://www.gdrc. org/uem/define-squatter.html

Tebbal, F., \& Ray, K. (2001). Housing the urban poor. Habitat Debate, 7(3), 1-5.

UNHCS (United Nations Centre for Human Settlements). (1996). Human settlements and the urban poor: Specific recommendations. Habitat Debate, 2(2), 8-9.

Wakely, P. (2010). Approach to the low-income housing. UN Habitat.

Wilcox, D. (1994). The guide to effective participation. Brighton: Delta Press.

Wilson, J. R., \& Corlett, N. (2005). Evaluation of human work (3rd ed.). Boca Raton, FL: CRC Press. 